\title{
VAPB Gene
}

National Cancer Institute

\section{Source}

National Cancer Institute. VAPB Gene. NCI Thesaurus. Code C124935.

This gene plays a role in the endoplasmic reticulum unfolded protein response. 